\title{
The Development of Vocabulary Memorization by Using Games
}

\author{
Wichuda Kunnu, Thanakorn Uiphanit, and Aungkana Sukwises
}

\begin{abstract}
The research of "The Development of Vocabulary Memorization by Using Games" has the objective to compare a learning achievement between pre-learning and post-learning by using games. The target used in data collection was upper primary education students studying English clubs for 7 weeks. Instructors selected 5 categories of words, namely items in school, clothing, food, occupation and weather, emphasizing on memorization by using games such as bingo, crossword puzzle, word matching and picture and word spelling. A test was conducted before and after instructions using the same test paper.

From the study results, it is found that an average testing score in pre-learning and post-learning in word and items in school categories are different with statistical significance at 0.05. Moreover, when considering the average scores in each word categories, it is found that the average score of test papers in mixed word and weather having an average testing scores in pre-learning higher than post-learning; the other has the average testing scores lower in pre-learning lower that post-learning.
\end{abstract}

Index Terms-Vocabulary memorization, teaching vocabulary, vocabulary acquisition, ESL.

\section{INTRODUCTION}

In the age of technology and information, language is an important media in transferring data and to be a media between human, especially English language which is considered to be the World English, people around the world can communicate by using English as main language; therefore, English is determined to be a basic language to be taught in education institute.

Words are an element that is considered to be the heart of language. Many words to be learned by learners and to be able to use correctly in listening, speaking and writing skills could help in learning English well.

Learning English according to the Basic Education Curriculum of Ministry of Education in learning English. T. Huckin and J. Coady mentioned an importance of words that the learning of words is necessary and it is necessary to ability in comprehensive reading in every education level of English language learners to be a first language and second language [1].

The more higher education level, the more necessity in word learning is needed. As for the instruction in English of Thai students, it is found that there are problems related to words all along; the problems can be noticed from the students who are unable to read the word correctly. Those students are only relied on principles taught by instructors, causing problems in pronunciation and other following problems, namely lacking of confidence in reading or speaking English and permanence in word memorization; as the aforementioned examples, it could be said that the development of ability related to English words is necessary and significantly important, helping learners to accumulate better standard proficiency in English. Instruction in English has many types of media that could be used in teaching. Games are the one of the interesting type because teaching English by using games is to urge learners to have a good attitude towards the instruction. Learners will be fun and able to play and learn; the learners will not feel that they are forced to learn in conformity with the research of [2]. That is to said, Games are the methods to practice English, which are significantly effective in learning language as learners are fun in learning, making the learners feel enthusiasm and courage to use English. From experience in teaching English of the author, it is the same as aforementioned; if any class brings games to be used in classroom, it will make learners feeling fun and attention more than an ordinary class; therefore, a memorization of English word by using games may help solving memorization in English word of learners. Moreover, as in the research of [3] claimed that students' learning preferences are activists, whose characteristics are learning by doing, enjoying working with others, being ready to learn from new experiences including doing activities freely, and preferring emotional learning to long lecture.

The research aims to study learning results between pre-learning and post-learning by using games.

\section{OBJECTIVES}

The study was conducted with the aim of comparing learning achievement between pre-learning and post-learning by using games. The students should do the pretest before learning.

\section{DELIMITATION OF RESEARCH}

The scope of this research is limited the population is the learners in upper primary education of Dipangkornwittayapat (Watbot), who study in English club. The upper primary education in Thailand is the students who study in grade 4-6. The total of students who attend the club about 21 persons.

\section{EXPECTED OUTCOME}

After the students study English vocabulary seven weeks,
Manuscript received December 25, 2014; revised February10, 2015.
The authors are with the Faculty of Humanities and Social Sciences, Suan Sunandha Rajabhat University, Bangkok, Thailand (e-mail: wichuda.ku@ssru.ac.th, wkunnu@gmail.com, thanakorn.ui@ssru.ac.th, aungkana.su@ssru.ac.th). 
the researcher hopes that the learners have accuracy in spelling and writing English word. The learners can remember the meaning of each word by playing games. The learners are fun and happy with English word learning by several types of games.

\section{DEFINITION}

1) Upper primary education are namely education year 4 to year 6.

2) Primary students are students who study grade 1-3.

3) Vocabulary memorization is a way to make students remember vocabulary.

4) Vocabulary is defined as words in a specific language or freestanding items of language that have meaning.

\section{RELEVANT RESEARCHES}

The research "the development of vocabulary memorization by using games"has relevant and connected researches divided into 2 issues as follows:

\section{A. Methodology of English Words Teaching}

S. Pongthongcharoen from a book teaching method of English as second language suggests the steps in teaching words as follows [4]:

1) Considering difficulty of words: teachers should consider that such word is a difficult word or easy word or problematic word in order to divide and search for teaching methods and training to be suitable with that word.

2) Practice in pronunciation of new words: teacher writes new words on a board and read for students at first and makes the students pronounce along with teacher; at the same time, teacher has to correct a wrong pronunciation word.

3) Teaching of meaning: teacher makes the students to interpret a meaning from English directly and should avoid using Thai; teacher could use tools for facilitate, namely chart, picture, real object or acting to make the students understand in the meaning clearly. As for the strategy in teaching of meaning to avoid Thai, it has many forms which should help the students understand in meaning of words from English directly as follows:

- Using words which students know or from environment of the students to tie with sentence in order to connect to a meaning of new words

- Using sentence of old words when the meaning is the same or opposite with new words

- Teaching new words by limiting a meaning to easy level

- Using picture or real object for explaining meaning: this kind of equipment could be brought for use easily, namely things around a room, uniform or some part of a body or using lined pattern picture, cartoon or drawing on a black board; this equipment could help in expressing the meaning clearly without using translated words.
- Acting: teachers are able to use acting with expressing meaning of words.

- Using context or teaching to predict meaning from sentence

In addition, students should be trained to use words in sentence and should not be trained with single word; the sentences to be used in training should be correct and could be used in real situation and should be known by the students. Teachers must not teach new words in new forms of sentences but should find a method of adding word by using several training methods as follows:

1) Find the same meaning words.

2) Find the different meaning words.

3) Find the same root words.

4) Find the words having meaning in the same group.

5) Study parts of speech.

6) Practice to add prefix and suffix into the words known by students.

\section{B. Relevant Researches with Using Word Game in Teaching}

S. Samnao has conducted a study regarding a result in using games in teaching making endurance in learning English words of primary students, year 5 of Assumption College Rayong; it is found that the using games in teaching in teaching, helping students to gain endurance in learning English words after learning for 2 weeks. Students like the activity of word games used in teaching in highest level [5].

S. Fuangkarn has conducted a study in comparison between an achievement and endurance in learning meanings, words and attitude towards English of primary education students, year 6, learning by having games and not having games; it is found that the primary education students, year 6 , learning by having games in teaching of meanings of English words have an achievement in learning and endurance in learning word meaning and attitude towards learning of English higher than the group not having games in the teaching [6].

S. Sittironnarit the development of media enhancing learning skills of English words in daily life by animation cartoon for primary education students, year 3 , an achievement of learning of English words in daily life of students before and after using media enhancing learning skills by having achievement score in learning of English words after using media enhancing learning skills higher than before using media enhancing learning skill [7].

\section{Research Methodology AND DAta Collection}

Data collection was conducted as following steps:

1) The sample group conducted pre-test for 15 questions for 30 minutes in order to measure knowledge in English words.

2) Teachers taught for 7 weeks and 1 hour per week. The researchers conducted data collection for students of English club, upper primary education, namely primary education, year 4 , year 5 and year 6 , total 25 people.

A time period for conducting data collection is from students of English club having class on Wednesday from 08.45-09.45 hours as below schedule: 
TABLE I: SCHEDULE AND CONTENT OF TEACHING

\begin{tabular}{ll}
\hline \hline Week $(\mathrm{s})$ & Teaching Content \\
\hline $1^{\text {st }}$ Week & Pre Test \\
\hline $2^{\text {nd }}$ Week & Items in School \\
\hline $3^{\text {rd }}$ Week & Places in town \\
\hline $4^{\text {th }}$ Week & Clothes \\
\hline $5^{\text {th }}$ Week & Food \\
\hline $6^{\text {th }}$ Week & Occupation \\
\hline $7^{\text {th }}$ Week & Weather , Post Test \\
\hline \hline
\end{tabular}

For the first time of learning of learners, they had to do a pre-test of words in all categories while before starting classes in each period, the researchers spent 10 minutes to allow the learners do a test in word categories taught in that day and after the classes were finished, there would be a post test in each class using the same test paper as in the pre-test.

3) After teaching for 7 weeks completely, the sample group did a post test of word by using the former test paper.

\section{DEFINITION OF POPULATION SAMPLE}

The population group used in this research is as follows: primary students, year 4 , year 5 and year 6 , total 25 persons, divided 9 primary students, year $4 ; 8$ primary students; 8 primary students.

\section{TOOLS IN DATA COLLECTION}

The tools used in data collection of this research are pre test and post test. A pre test and post test are the same set of test paper. The tests used in this research are 6 sets:

1) $1^{\text {st }}$ set: The consolidated test paper of English words, total 15 clauses, the quizzes are matching quizzes between pictures and words, the 1st test paper is used as pre test and post test.

2) $2^{\text {nd }}$ set: The English word test of items in classroom, total 10 clauses, the questions are matching questions between pictures and words.

3) $3^{\text {rd }}$ set: The English word test of clothing, total 9 clauses, the questions are "filling in the blank" in determined words.

4) $4^{\text {th }}$ set: The English word test of food, total 6 clauses, the questions are switching letter quizzes to make a correct answers.

5) $5^{\text {th }}$ set: The English word test of occupation, total 9 clauses, the questions are "filling in the blank in determined words.

6) $6^{\text {th }}$ set: The English word test of air, total 7 clauses, the questions are "filling in the blank" in determined words.

\section{Results Of RESEARCH}

According to above tablet, it demonstrates the comparison of average testing score between pre-learning and post-learning dividing according to the groups of test papers by paired samples test, giving results as average testing scores of pre test and post test in the groups of mixed test papers having statistically significant difference $(\mathrm{Sig} .=0.675)$. The average testing scores of pre test and post test in word groups in occupation are not different $(\mathrm{Sig} .=0)$. The average testing scores of pre test and post test in word groups in things in school are different $($ Sig. $=0.116)$. The average testing scores of pre test and post test in word groups in food are not different $($ Sig. $=0.008)$. The average testing scores of pre test and post test in word groups in categories are not different $($ Sig. $=0)$ and The average testing scores of pre test and post test in word groups in clothing are not different (Sig. =0). The average testing scores of pre test and post test in word groups in weather are not different $(\mathrm{Sig} .=0.001)$ having confidence levels at $95 \%($ Alpha $=0.05)$

TABLE II: DEMONSTRATION OF COMPARISON OF AVERAgE TESTING SCORE BETWEEN PRE-LEARNING AND POST-LEARNING DIVIDING ACCORDING TO THE GROUPS OF TEST PAPERS BY PAIRED SAMPLES TEST

\begin{tabular}{|c|c|c|c|c|c|c|c|c|}
\hline & \multicolumn{5}{|c|}{ Pair Samples Test } & \multirow{3}{*}{$t$} & \multirow{3}{*}{$d f$} & \multirow{3}{*}{$\begin{array}{c}\text { Sig. } \\
\text { (2-tailed) }\end{array}$} \\
\hline & \multirow{2}{*}{ Mean } & \multirow{2}{*}{$\begin{array}{l}\text { Std } \\
\text { Deviation }\end{array}$} & \multirow{2}{*}{$\begin{array}{l}\text { Std. Error } \\
\text { Mean }\end{array}$} & \multicolumn{2}{|c|}{$\begin{array}{l}\text { 95\% Confidence Interval of } \\
\text { the Difference }\end{array}$} & & & \\
\hline & & & & Lmext & $v_{\text {neser }}$ & & & \\
\hline $\begin{array}{l}\text { Pair 1 } \\
\text { Mix_Pre-Mix_- } \\
\text { Post }\end{array}$ & .3600 & 4.24146 & .84829 & -1.3908 & 2.1108 & . 424 & 24 & $.67:$ \\
\hline $\begin{array}{l}\text { Pair } 2 \text { Occ_Pre } \\
\text {-Occ_Post }\end{array}$ & $\begin{array}{r}-2.400 \\
0\end{array}$ & 2.10159 & .42032 & -3.2675 & -1.5325 & -5.710 & 24 & .000 \\
\hline $\begin{array}{l}\text { Pair 3 Sch_Pre- } \\
\text { Sch_Post }\end{array}$ & .8400 & 2.57682 & .51536 & -1.9037 & .2237 & -1.630 & 24 & .116 \\
\hline $\begin{array}{l}\text { Pair4 Food_Pre } \\
\text {-Food_Post }\end{array}$ & .8400 & 1.46287 & .29257 & -1.4438 & .2362 & -2.871 & 24 & .008 \\
\hline $\begin{array}{l}\text { Pair } 5 \text { Clo_Pre - } \\
\text { Clo_Post }\end{array}$ & $\begin{array}{r}-2.360 \\
0\end{array}$ & 1.75309 & .35062 & -3.0836 & -1.6364 & -6.731 & 24 & .000 \\
\hline $\begin{array}{l}\text { Pair } 6 \text { Wea_Pre } \\
\text { - Wea_Post }\end{array}$ & $\begin{array}{r}1.640 \\
0\end{array}$ & 2.23383 & .44677 & .7179 & 2.5621 & 3.671 & 24 & .001 \\
\hline
\end{tabular}

TABLE III: NUMBER OF LEARNERS DOING TEST TO COLLECT TOTAL SCORES IN PART OF PRETEST AND POSTTEST

\begin{tabular}{lc|c|c|c|c|c}
\hline & $N$ & $\begin{array}{l}\text { Mini } \\
\text { mum }\end{array}$ & Maximum & \multicolumn{2}{c|}{ Mean } & Std. \\
\cline { 2 - 8 } & Statistic & Statisic & Statistic & Statistic & Std. Error & Statistic \\
\hline Mix_Pre & 25 & 12.00 & 15.00 & 13.0800 & .1143 & .57155 \\
\hline Mix_Post & 25 & 1.00 & 15.00 & 12.7200 & .8632 & 4.31586 \\
\hline Occ_Pre & 25 & 1.00 & 9.00 & 5.0800 & .4723 & 2.36150 \\
\hline Occ_Post & 25 & 5.00 & 9.00 & 7.4800 & .2458 & 1.22882 \\
\hline Sch_Pre & 25 & 1.00 & 10.00 & 8.0800 & .5829 & 2.91433 \\
\hline Sch_Post & 25 & 3.00 & 10.00 & 8.9200 & .3210 & 1.60520 \\
\hline Food_Pre & 25 & 1.00 & 6.00 & 3.8800 & .2471 & 1.23558 \\
\hline Food_Post & 25 & 1.00 & 6.00 & 4.7200 & .3292 & 1.64621 \\
\hline Clo_Pre & 25 & 1.00 & 8.00 & 5.1200 & .3479 & 1.73973 \\
\hline Clo_Post & 25 & 2.00 & 9.00 & 7.4800 & .3835 & 1.91746 \\
\hline Wea_Pre & 25 & 1.00 & 8.00 & 6.6000 & .4359 & 2.17945 \\
\hline Wea_Post & 25 & 1.00 & 8.00 & 4.9600 & .4061 & 2.03060 \\
\hline Valid N & 25 & & & & & \\
(listwise) & & & & & & \\
\hline \hline
\end{tabular}

Table III it demonstrates number of learners doing test to collect total scores in part of pretest and posttest. The scores in part of test paper in categories of mixed words and weather have the average testing scores higher that posttest; moreover, the average testing average.

It is possible that regarding the word category of weather and mixed words, learners did posttest of test paper in the same day, that is to say, in 7th week which was the last week; this week the learners have to learn a word category of weather and do a test in weather category. When finishing learning in the weather category, the learners have to review all learned knowledge by doing posttest of mixed word category in limited time and doing 2 test papers at the same time; therefore, this would make the scores in posttest results to have lower average scores before pretest. 


\section{DISCUSSION}

From the research of "The Development of Vocabulary Memorization by Using Games", the researchers are able to discuss on the results as follows:

\section{A. The Comparison of an Achievement between Pre-learning and Post-learning}

According to an observation in behavior or the learners, it is found that the learners are interested in English learning through activities very well, enthusiasm and concentrated. The learners obtain skills from learning activities, namely matching pictures with words, playing crossword, filling in the blank; the every activity in playing games creates competition and the winner will get the prize. Using the prize as incentive will make the learners be in attempt and fun, being ready to engage in activities and memorize words at the same time by not feeling that they are forced to learn.

From the study results, it is shown that the average scores in posttest are higher than pretest even some category of words may have different achievement by not having statistical significance. The testing of pretest and posttest of mixed word categories and things in school having an achievement value between pretest and posttest differently with statistical significance, it is shown that using games to develop memorization in words of the learners is effective and noted that in the period of 7 weeks, the learners returned to do a test in mixed word categories which are the same test paper with pretest and posttest; consequently, the testing results in such category have statistically significant different, it is shown that the memorization of the learners has endurance and do not lose.

However, problems which are found are the memorization of English words by using games as above-mentioned that a competition is arranged, causing some group of learners aiming to win in order to get the prize, which, sometime, make them shout to cheer a team member and not pay attention to memorize some words.

\section{B. Results of Discussion for Exchanging Feeling with Learners after Learning}

At last week of class, the researcher had an opportunity to ask the learners on feeling in learning English by using game; most learners gave opinions that they are fun and happy in participating activities and some learners who got the prize are happy specially. Some learners told that they told that they got the prize in participation of acting activities; this means that the using of prize to give to the learners will be an incentive to make the learners have more motivation and affect the learners to be enthusiasm, trying to learn, which will lead to the learning with happiness without pressure as they have to expect the received grade in conformity with [8] they said that when the students are interested and fun with learning, the perception will be higher, affecting the students to learn better and increase learning achievement results.

\section{SUGGESTION}

1) Activities should be increased for happiness between the learning in classes.

2) Teaching of English words may focus on doing other activity having several diversity, namely, singing a song and acting to be used in games.

\section{ACKNOWLEDGMENT}

This is in the acknowledgement of funding by Suan Sunandha Rajabhat University's personnel development fund for this occasion.

\section{REFERENCES}

[1] T. Huckin and J. Coady, "Incidental vocabulary acquisition in a second language," Studies in Second Language Acquisition, vol. 21, no. 2, pp 181-193, 1999.

[2] A. Wiriyachitra, Communicative Language Teaching and Learning, Bangkok: Aksorncharoentat, 2002.

[3] C. Tantarangsee, "Learning styles of university students in bangkok: The characteristics and the relevant instructional context," World Academy of Science, Engineering and Technology, International Science Index 73, vol. 7, no. 1, pp. 480-487, 2013.

[4] S. Pongthongcharoen, Teaching English as a Second Language, Bangkok: Srinakharinwirot University, 2006.

[5] S. Samnao, "The study of the effect vocabulary games on the retention in learning vocabulary of Prathomsuksa five learners of Assumption College Rayong," MA Research Paper, Srinakharinwirot University, 2004.

[6] S. Fuangkarn, “A comparison of prathomsuksa 6 students' vocabulary achievement, retention, and attitudes toward English language learning using game and non-game techniques," M.Ed. Research Paper, Chiangmai University, 1988.

[7] S. Sittironnarit, "The development of media for enhancing English vocabulary skills in everyday life by using cartoon animation for ninth graders," MA Research Paper, Silpakorn University, 2008.

[8] P. A. R. Amato, Making It Happen: From Interactive to Participatory Language Teaching, Pearson ESL, 2003.

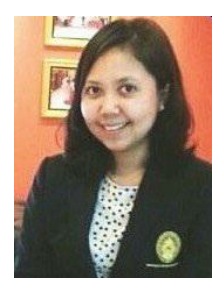

Wichuda Kunnu was born on December 16, 1982 in Songkhla, Thailand. She got a bachelor degree in English major from Bangkok University, Thailand. After that she graduated with a master degree in linguistics for communication from Thammasat University, Thailand. Now she is a lecturer in English major, Faculty of Humanities and Social Sciences, Suan Sunandha Rajabhat University (SSRU), Bangkok, Thailand. She is interested in ELT English language teaching and EIL English as an international language.

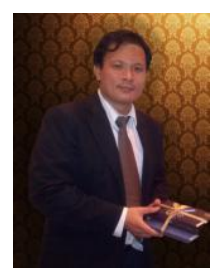

Thanakorn Uiphanit was born on February 19, 1980 in Chiang Mai, Thailand. He got a bachelor degree of arts in library and information sciences from Khon Kaen University and bachelor of law from Thammasat University, Thailand and master of science degree in information technology from King's Mongkut University of Technology Thonburi. Now he is studying doctor of philosophy program in technopreneurship and innovation management at Chulalongkorn University. He is a lecturer in library and information sciences, Faculty of Humanities and Social Sciences, Suan Sunandha Rajabhat University, Bangkok, Thailand. He is interested in innovation management and library technology.

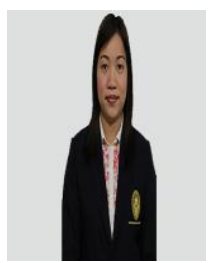

Aungkana Sukwises got bachelor of arts degree from (English language and literature) Thammasat University, 1996. She received master of arts degree from (comparative literature) Chulalongkorn University, 2001. She also interested in movies and television scripts translation, English for hotel and restaurant chain, English and American literature. 